\author{
ANDRZEJ SAKOWICZ \\ ORCID: 0000-0001-6599-4876 \\ Uniwersytet w Białymstoku
}

\title{
ODPOWIEDZIALNOŚĆ KOMORNIKA SĄDOWEGO ZA NIEPRAWIDŁOWE ROZLICZENIE OPŁATY EGZEKUCYJNEJ NA PODSTAWIE PRZEPISÓW KODEKSU KARNEGO SKARBOWEGO
}

\begin{abstract}
Abstrakt: Artykuł przedstawia nowe typy czynów zabronionych dotyczących odpowiedzialności komornika sądowego za nieprawidłowe rozliczenie opłaty egzekucyjnej na podstawie przepisów kodeksu karnego skarbowego. Autor analizuje znamiona nowych przestępstw (art. 57a i 57b k.k.s) oraz dokonuje ich krytycznej oceny w kontekście zasady proporcjonalności oraz spójności wewnętrznej przepisów kodeksu karnego skarbowego. W końcu dochodzi do wniosku, że brakuje racjonalnego uzasadnienia przyjęcia nowych przestępstw związanych z odpowiedzialnością karną komornika sądowego.
\end{abstract}

Słowa kluczowe: komornik sądowy, Kodeks karny skarbowy, odpowiedzialność karnoskarbowa, racjonalny prawodawca

\section{WPROWADZENIE}

Odpowiedzialność karnoskarbowa komornika sądowego od wielu lat budziła liczne kontrowersje. W szczególności wiązały się one z jednoczesną rolą komornika jako płatnika podatku od towarów i usług. Dokonując sprzedaży egzekucyjnej towarów, komornicy sądowi byli obowiązani do obliczenia, pobrania i wpłacenia podatku VAT we właściwym terminie organom podatkowym. Teza ta znajdowała poparcie w treści art. 18 ustawy z dnia 11 marca 2004 roku o podatku od towarów i usług (dalej: ustawa o VAT) ${ }^{1}$, który stanowił, że organy egzekucyjne określone w ustawie z dnia 17 czerwca 1966 roku o postępowaniu egzekucyjnym w administracji ${ }^{2}$ oraz komornicy sądowi wykonujący czynności egzekucyjne w rozumieniu przepisów kodeksu postępowania cywilnego są płatnikami podatku od dostawy dokonywanej w trybie egzekucji, towarów będących własnością dłużnika lub po-

1 Dz.U. z 2004 r. Nr 54, poz. 535 ze zm.

2 Dz.U. z 2002 r. Nr 110, poz. 968 ze zm. 
siadanych przez niego z naruszeniem obowiązujących przepisów. Z literalnego brzmienia powyższego przepisu wynikało, że jedynym warunkiem koniecznym dla uznania komornika sądowego za płatnika podatku od towarów i usług od dostawy dokonanej w trybie egzekucji jest wykonywanie przez niego czynności egzekucyjnych. Powyższy pogląd wzmacniała treść art. 2 ustawy z dnia 29 sierpnia 1997 roku o komornikach sądowych i egzekucji ${ }^{3}$ stanowiąca, że komornik sądowy wykonuje czynności egzekucyjne w sprawach cywilnych oraz inne czynności przekazane na podstawie odrębnych przepisów.

I tak na przykład z art. $759 \S 1$ k.p.c. wynika, że czynności egzekucyjne są wykonywane przez komorników, z wyjątkiem czynności zastrzeżonych dla sądów. Należy zauważyć, że na określony rodzaj egzekucji (na parzykład egzekucję z nieruchomości) składa się szereg czynności egzekucyjnych, z których tylko nieliczne wykonywane są przez sąd. Wykonywanie przez sąd niektórych czynności, takich jak przybicie, wezwanie do złożenia do depozytu sądowego oraz przysądzenie, które skutkują przeniesieniem własności nieruchomości na nabywcę, nie oznacza, że w przypadku egzekucji z nieruchomości komornik nie wykonuje żadnych czynności egzekucyjnych. W trakcie egzekucji z nieruchomości w trybie egzekucji publicznej komornik wykonuje szereg czynności egzekucyjnych takich jak: zajęcie nieruchomości poprzez wysłanie stosownych pism dłużnikowi i sądowi, opis i oszacowanie, obwieszczenie o licytacji, przyjęcie rękojmi, przeprowadzenie i zamknięcie licytacji pod nadzorem sędziego. W związku z powyższym zasadnie twierdzono, że w świetle art. 18 ustawy o VAT ${ }^{4}$ komornik sądowy był płatnikiem podatku od dostawy dokonanej w wyniku prowadzenia określonego rodzaju egzekucji, jeżeli podejmuje czynności egzekucyjne. Rodziło to szereg problemów, w szczególności komornik nie wiedział — z powodu braku współpracy ze strony dłużnika, którego majątek był licytowany — czy są spełnione warunki do zastosowania przy takiej licytacji zwolnienia z VAT. Była to jedna z kluczowych kwestii,

3 Dz.U. z 1997 r. Nr 133, poz. 882 ze zm.

${ }^{4}$ Zdaniem Trybunału Konstytucyjnego przepis art. 18 ustawy o VAT w sposób niebudzący wątpliwości wskazywał, że komornik sądowy jest płatnikiem podatku od dostawy dokonanej w wyniku prowadzenia określonego rodzaju egzekucji ilekroć podejmuje on czynności egzekucyjne. Przy czym brak jest jednoznacznego wymogu, aby komornik jako przyszły płatnik dokonywał — $\mathrm{w}$ trakcie prowadzenia określonego rodzaju egzekucji — czynności, której bezpośrednim skutkiem jest przeniesienie prawa własności określonego towaru. W ocenie TK ustanowienie organu egzekucyjnego (w tym komornika sądowego) płatnikiem podatku od towarów i usług ma zapewnić odprowadzenie należnego podatku od sprzedaży w ramach postępowania egzekucyjnego, a zatem w sytuacji, gdy istnieją podstawy do przyjęcia, że podatnik będący niesolidnym dłużnikiem nie będzie skory do uiszczenia podatku należnego w związku $\mathrm{z}$ dostawą mającą miejsce $\mathrm{w}$ toku egzekucji, zob. wyrok Trybunału Konstytucyjnego z 4 listopada 2010 roku (sygn. P 44/07, OTK-A 2010, nr 9, poz. 97; por. A. Bartosiewicz, R. Kubacki, VAT. Komentarz, Warszawa 2007, s. 263-265; M. Kalinowski, Komornik jako płatnik podatku od towarów i ustug. Uwagi na marginesie uchwaty Sądu Najwyższego z dnia 15 grudnia 2006 roku, III CZP 115/06, „Przegląd Prawa Egzekucyjnego” 2008, nr 6-9, s. 8; P. Wojnicz, Status komornika jako płatnika podatku VAT w egzekucji sadowej, „Przegląd Prawa Egzekucyjnego” 2007, nr 1-2, s. 46. 
ponieważ komornik sądowy był płatnikiem podatku od towarów i usług tylko wówczas, gdy do rozliczenia tego podatku z tytułu sprzedaży byłby zobowiązany dłużnik. Po spełnieniu określonych warunków nabycie takiego statusu przez komornika sądowego otwierało możliwość poniesienia przezeń odpowiedzialności karnoskarbowej za niepobranie podatku VAT (art. 78 k.k.s.), niewpłacenie w terminie pobranego podatku (art. 77 k.k.s.), niezłożenie informacji podatkowej (art. $80 \S 2$ k.k.s.) albo też niedopełnienie obowiązku nadzoru (art. 84 k.k.s.) $)^{5}$.

Wejście w życie nowej ustawy z dnia 22 marca 2018 roku o komornikach sądowych (dalej: ustawa o KS) ${ }^{6}$ zmieniło ich status z dniem 1 stycznia 2019 roku. Zgodnie $\mathrm{z}$ art. 3 ust. 1 ustawy o KS, komornik jest organem władzy publicznej $\mathrm{w}$ zakresie wykonywania czynności w postępowaniu egzekucyjnym i zabezpieczającym, zaś norma określona w art. 33 tej ustawy wskazuje, że komornik sądowy nie jest już przedsiębiorca i nie może prowadzić działalności gospodarczej. Zakaz prowadzenia działalności gospodarczej przez komornika sądowego powoduje, że traci on status płatnika VAT, którym jest — zgodnie z art. 15 ust. 1 ustawy o VAT - osoba prawna, jednostka organizacyjna nieposiadająca osobowości prawnej i osoba fizyczna, o ile w każdym przypadku działalność gospodarczą wykonuje samodzielnie. Wydawać by się mogło, że nabycie przez komornika sądowego statusu organu władzy publicznej rozwiąże problemy w zakresie jego odpowiedzialności karnoskarbowej. Spostrzeżenie to jest jednak trafne tylko w połowie. $Z$ jednej strony nowa ustawa o komornikach sądowych bezspornie wyklucza ich z zakresu podatku VAT, a tym samym z zakresu stosowania norm prawnokarnoskarbowych. Z drugiej - nowa ustawa o komornikach sądowych wprowadziła dwa nowe typy czynów zabronionych (art. 57a i 57b k.k.s.), które wyrażają prawnokarną ochronę opłaty egzekucyjnej.

Celem niniejszego opracowania jest przedstawienie istoty przestępstwa zatrzymania opłaty egzekucyjnej (art. 57a k.k.s) oraz przestępstwa niezłożenia informacji o uzyskanych opłatach egzekucyjnych (art. 57b k.k.s), a także udzielenie odpowiedzi na pytanie o zasadność wprowadzenia nowych typów czynów zabronionych do Kodeksu karnego skarbowego. Przyjęta perspektywa badawcza będzie wiązała się z analizą ustawowych zmian obu typów oraz miejscem ich ulokowania w kodeksie. Będzie ona prowadzona z pominięciem uzasadnienia projektu ustawy o komornikach sądowych ${ }^{7}$, gdyż projektodawca nie wskazał w nim jakichkolwiek motywów uzasadniających potrzebę wprowadzenia typów czynów zabronionych z art. 57a i 57b k.k.s. Wprowadzenie wskazanych typów czynów zabronionych dziwi tym bardziej, że opłata egzekucyjna stanowi niepodatkową należność budżetową o charakterze publicznoprawnym pobieraną za wykonywanie: a) orzeczeń sądowych w sprawach o roszczenia pieniężne i niepieniężne oraz o za-

5 Szerzej zob. F. Nalikowski, Odpowiedzialność karna skarbowa komornika sądowego jako płatnika podatku od towarów i usług, „Prawo Budżetowe Państwa i Samorządu” 2016, nr 1, s. 43-55.

6 Dz.U. z 2020 r. poz. 121.

7 Druk nr 1582 Sejmu VIII kadencji. 
bezpieczenie roszczeń, w tym europejskich nakazów zabezpieczenia na rachunku bankowym, b) innych tytułów wykonawczych oraz tytułów egzekucyjnych, które podlegają wykonaniu w drodze egzekucji sądowej bez zaopatrywania ich w klauzulę wykonalności oraz postanowień o zabezpieczeniu środka dowodowego oraz postanowień nakazujących wydanie środka dowodowego w postępowaniu w sprawach własności intelektualnej (art. 149 w zw. z art. 3 ust. 3 pkt 1-2a ustawy o KS) na zasadach określonych w ustawie $\mathrm{z}$ dnia 28 lutego 2018 roku o kosztach komorniczych. Nie stanowi ona zatem ani należności podatkowej, ani dotacji czy subwencji, o których mowa w rozdziale 6 („Przestępstwa skarbowe i wykroczenia skarbowe przeciwko obowiązkom podatkowym i rozliczeniom z tytułu dotacji lub subwencji") Kodeksu karnego skarbowego. Rodzi się zatem pytanie o zasadność umieszczenia obu nowych typów czynów zabronionych w tym kodeksie.

\section{PRZESTĘPSTWO ZATRZYMANIA OPŁATY EGZEKUCYJNEJ}

W art. 57a k.k.s. zostało ujęte przestępstwo zatrzymania opłaty egzekucyjnej przez komornika sądowego. Jego istota polega na ponoszeniu odpowiedzialności karnoskarbowej przez komornika sądowego za nieprzekazanie na rachunek właściwego urzędu skarbowego opłat egzekucyjnych podlegających przekazaniu albo przekazaniu ich w niewłaściwej wysokości. Przedmiotem ochrony stypizowanego w art. 57a k.k.s. przestępstwa skarbowego ( $\$ 1$ i 2 ) oraz wykroczenia skarbowego (§3) jest należność budżetowa o charakterze publicznoprawnym oraz prawidłowość rozliczenia się z tytułu uzyskanych opłat egzekucyjnych ${ }^{8}$. Zgodnie bowiem $\mathrm{z}$ art. 149 ust. 2 ustawy o KS uzyskane opłaty egzekucyjne, po potrąceniu wynagrodzenia prowizyjnego komornika, stanowią dochód budżetu państwa i podlegają przekazaniu na rachunek urzędu skarbowego właściwego ze względu na siedzibę kancelarii w terminie do piątego dnia miesiąca kalendarzowego następującego po miesiącu, w którym zostały uzyskane. Zastrzec przy tym należy, że przez uzyskane opłaty egzekucyjne rozumie się opłaty faktycznie pobrane lub ściągnięte na podstawie przepisów ustawy z dnia 28 lutego 2018 roku o kosztach komorniczych. Dostrzegając fakt, że opłata egzekucyjna nie jest wykonaniem obowiązku podatkowego, trzeba jednoznacznie stwierdzić, że delikt karnoskarbowy z art. 57a k.k.s. nie ma wiele wspólnego z pozostałymi przestępstwami i wykroczeniami skarbowymi stypizowanymi w kodeksie. Prawdopodobną przyczyną jego ulokowania w kodeksie jest okoliczność, że opłata egzekucyjna stanowi dochód budżetu państwa, zaś jej uiszczenie następuje na rachunek urzędu skarbowego. Niezależnie od tego brakuje powiązania przedmiotu ochrony art. 57a k.k.s. (a także art. 57b k.k.s.) z innymi typami czynów zabronionych, które znalazły się

8 Na drugi element wskazuje S. Kowalski, Czyny zabronione dotyczace opłat egzekucyjnych w Kodeksie karnym skarbowym, „Przeglad Prawa Egzekucyjnego” 2020, nr 1, s. 22. 
w rozdziale 6 Kodeksu karnego skarbowego ${ }^{9}$. W konsekwencji podważa to sens umieszczenia obu nowych typów czynów zabronionych w KKS. Wątpliwość jeszcze pogłębia fakt, że wprowadzając odpowiedzialność karnoskarbową komornika sądowego, ustawodawca odstąpił od penalizacji na gruncie rozdziału 6 Kodeksu karnego skarbowego li tylko podmiotów właściwych prawu podatkowemu, to jest podatnika płatnika i inkasenta ${ }^{10}$, jako że w art. 57a i 57b k.k.s. przewidział odpowiedzialność karnoskarbową funkcjonariusza publicznego. Zgodnie z art. 2 ust. 1 ustawy o KS komornik jest funkcjonariuszem publicznym działającym przy sądzie rejonowym oraz — jak stanowi art. 3 tejże ustawy — organem władzy publicznej w zakresie wykonywania czynności w postępowaniu egzekucyjnym i zabezpieczającym.

Przechodząc do analizy strony przedmiotowej czynu zabronionego z art. 57a k.k.s., należy najpierw stwierdzić, że jego podmiotem może być przede wszystkim komornik sądowy. Popełnienie tego czynu zabronionego przez osobę nieposiadającą statusu komornika sądowego może nastąpić jedynie w warunkach art. $9 \S 3$ k.k.s., a więc wyłącznie w sytuacji, gdy osoba taka działa w zastępstwie komornika sądowego. Chodzi zatem o taką osobę, która na podstawie przepisu prawa, decyzji właściwego organu, umowy lub faktycznego wykonywania zajmuje się sprawami gospodarczymi, zwłaszcza finansowymi, osoby fizycznej, osoby prawnej albo jednostki organizacyjnej niemającej osobowości prawnej. Trafnie wskazuje się w doktrynie, że podmiotem o którym mowa w art. $9 \S 3$ k.k.s. może być księgowy rozliczający działalność komornika sądowego ${ }^{11}$, jeżeli z tytułu uzyskanych opłat egzekucyjnych narazi dochód budżetu państwa na uszczuplenie. Znajduje to potwierdzenie w orzecznictwie Sądu Najwyższego, w którym stwierdza się, że sprawcą przestępstwa odpowiadającym w oparciu o treść art. 9 § 3 k.k.s. może być między innymi doradca podatkowy zajmujący się, na podstawie umowy, sprawami gospodarczymi (w tym także finansowymi) osoby fizycznej, prawnej albo jednostki organizacyjnej niemającej osobowości prawnej, której przyznano zdolność prawną. Prowadzenie ksiąg rachunkowych przez doradcę podatkowego wyczerpuje znamię zajmowania się sprawami gospodarczymi ${ }^{12}$.

$\mathrm{O}$ ile podmiot przestępstwa $\mathrm{z}$ art. 57a k.k.s. nie budzi wątpliwości, o tyle rodzą się one na tle znamion określających czynność sprawczą. Została ona ujęta za pomocą dwóch znamion czasownikowych: nieprzekazanie opłaty egzekucyjnej na rachunek właściwego urzędu skarbowego oraz przekazanie je w niewłaściwej

9 Słusznie dostrzega S. Kowalski, że nie jest to pierwsze naruszenie systematyki Kodeksu karnego skarbowego. Po raz pierwszy nastąpi to wraz z dodaniem art. 76a i 76b k.k.s. Zob. ibidem; G. Łabuda, [w:] Kodeks karny skarbowy. Komentarz, red. P. Kardas, G. Łabuda, T. Razowski, Warszawa 2017, komentarz do art. 76a, pkt 1.

10 Tak trafnie S. Kowalski, op. cit., s. 24.

11 Ibidem.

12 Wyrok Sądu Najwyższego z dnia 22 lutego 2006 roku, III KK 213/05, OSNKW 2006, nr 5 , poz. 45 . 
wysokości. Pierwsze znamię czasownikowe — „nie przekazuje” — oznacza zaniechanie uiszczenia na rachunek właściwego urzędu skarbowego opłat egzekucyjnych podlegających przekazaniu. Termin ten nawiązuje wprost do normy prawnej wyrażonej w art. 149 ust. 2 ustawy z dnia 28 lutego 2018 roku o komornikach sądowych, wedle której uzyskane opłaty egzekucyjne, po potrąceniu wynagrodzenia prowizyjnego komornika, stanowią dochód budżetu państwa i podlegają przekazaniu na rachunek urzędu skarbowego właściwego ze względu na siedzibę kancelarii. Obowiązek przekazania został zakreślony na czas do piątego dnia miesiąca kalendarzowego następującego po miesiącu, w którym zostały uzyskane. Zasadnie wskazuje się w literaturze, że zaniechanie przekazania opłaty egzekucyjnej w powyższym terminie spowoduje, że z szóstym dniem miesiąca kalendarzowego zrealizowane zostaną znamiona strony przedmiotowej ${ }^{13}$.

Analizując treść wskazanych przepisów, można przyjąć, że środki pieniężne w postaci opłaty egzekucyjnej nie należą do komornika sądowego. Stanowią one należność budżetu państwa, zaś powinnością komornika jest jedynie obliczenie wysokości opłaty egzekucyjnej, potrącenie od niej wynagrodzenia prowizyjnego i wpłacenie pozostałej kwoty opłaty egzekucyjnej na rachunek właściwego urzędu skarbowego. W interpretacji znamienia czasownikowego ,nie przekazuje", którym operuje art. 57a $§ 1$ k.k.s., można posiłkować się orzecznictwem na podstawie art. $77 \S 1$ k.k.s. W tym ostatnim przepisie ustawodawca posłużył się zwrotem „nie wpłaca” w kontekście odpowiedzialności płatnika i inkasenta za niewpłacenie pobranego podatku w terminie na rzecz właściwego organu. Zwrot „nie wpłaca” oznacza „niewpłacenie na rachunek organu podatkowego obliczonego i pobranego podatku nie musi polegać na fizycznym przejęciu przez płatnika kwoty stanowiącej jego równowartość" ${ }^{14}$. W orzecznictwie sądowym stwierdzono także, że podatek jest pobrany wówczas, gdy dokonano jego potrącenia, to jest gdy wypłacono podatnikowi kwotę pieniężną po odliczeniu podatku podlegającego pobraniu ${ }^{15}$. Przenosząc powyższe uwagi na treść art. 57a k.k.s, można stwierdzić, że znamię czasownikowe „nie przekazuje” oznacza zaniechanie uiszczenia na rachunek urzędu skarbowego uzyskanej opłaty egzekucyjnej po potrąceniu wynagrodzenia prowizyjnego komornika. Każde bowiem zaniechanie w tym zakresie jest niewykonaniem prawnie nakazanego działania w określonym terminie. Ewentualne uiszczenie opłaty egzekucyjnej po terminie ma znaczenie tylko z perspektywy wymiaru kary. Dla naruszenia sankcjonowanej normy nie ma znaczenia także kondycja finansowa komornika sądowego.

13 S. Kowalski, op. cit., s. 27.

14 Wyrok Sądu Najwyższego z dnia 16 maja 2002 roku, IV KKN 427/98, „Prokuratura i Prawo” 2003, nr 2, poz. 12; wyrok Sądu Najwyższego z dnia 2 sierpnia 2002 roku, IV KKN 426/98, LEX nr 55193.

15 Wyrok Sądu Najwyższego z dnia 19 sierpnia 1999 roku, III KKN 434/97, „Prokuratura i Prawo" 2000, nr 1, poz. 16; wyrok Sądu Najwyższego z dnia 16 maja 2002 roku, IV KKN 427/98, „Prokuratura i Prawo” 2003, nr 2, poz. 12. 
Istota drugiego znamienia czasownikowego, jakim ustawodawca posłużył się w treści art. 57a $\S 1$ k.k.s., polega na przekazaniu przez komornika sądowego opłaty egzekucyjnej „w niewłaściwej wysokości”. Do momentu wejścia w życie ustawy z dnia 22 marca 2018 roku o komornikach sądowych, k.k.s. penalizował zachowania w postaci ,pobiera podatek w kwocie niższej od należnej” (art. 78 $\S 1$ k.k.s.). Nie podlegało natomiast penalizacji pobranie podatku w kwocie wyższej niż wynikała ze zobowiązania podatkowego, gdyż takie działanie nie mogło stanowić zamachu na dobro chronione prawem, czyli na mienie państwowe bądź na majątek samorządu terytorialnego. Odmiennie przedstawia się sytuacja na podstawie art. 57a $\S 1$ k.k.s. Tu bowiem ustawodawca posłużył się określeniem „W niewłaściwej wysokości”, które może sugerować, że „,ustawodawca wcale nie ograniczył zachowania sprawcy do zaniżenia wielkości przekazanej opłaty"16. Poprzestając na wykładni językowej, należałoby stwierdzić, że typ czynu zabronionego $\mathrm{z}$ art. 57a $\S 1$ k.ks. penalizuje „nieprzekazanie” opłaty egzekucyjnej zarówno w kwocie niższej niż wymagana, jak i w kwocie wyższej niż wynikająca $\mathrm{z}$ naliczenia na zasadach określonych w ustawie o kosztach komorniczych. Stawia to oczywiście pytanie o ratio legis takiego rozwiązania.

Czy oznacza to, że opłacie egzekucyjnej stanowiącej niepodatkową należność budżetową o charakterze publicznoprawnym przyznano wyższy standard ochrony niż podatkom? Wykładnia literalna wspiera takie stwierdzenie, trudno jednak je utrzymać, gdy następuje odwołanie się do elementów przestępstwa skarbowego. Każde przestępstwo skarbowe powinno cechować się subminimalnym (znikomym) stopniem społecznej szkodliwości (art. $1 \S 2$ k.k.s.). Takiego nie spełnia jednak przekazanie przez komornika sądowego opłaty egzekucyjnej w kwocie wyższej niż jest wymagana. W takim przypadku w ogóle nie następuje atak na dobro prawne, jakim jest niepodatkowa należność budżetowa o charakterze publicznoprawnym w postaci opłaty egzekucyjnej. Taki czyn jest pozbawiony cechy społecznej szkodliwości, a zatem nie może być zakwalifikowany jako czyn zabroniony ${ }^{17}$. Przedstawione uwagi skłaniają do poglądu, że penalizacja zachowań polegających na przekazaniu przez komornika sądowego opłaty egzekucyjnej „W niewłaściwej wysokości” wiąże się jedynie z sytuacją, gdy opłata egzekucyjna została przekazana w wysokości zaniżonej. Zrealizowanie jej następuje w dacie przekazania tej kwoty ${ }^{18}$.

Zachowanie karalne określone na gruncie art. 57a k.k.s. za pomocą znamion czynnościowych „nie przekazuje” na rachunek właściwego urzędu skarbowego

16 S. Kowalski, op.cit.

17 W tym zakresie można przywołać pogląd Sądu Najwyższego, zgodnie z którym ,nie ponosi odpowiedzialności karnej za dokonanie przestępstwa skutkowego osoba, której zachowanie nie stwarzało albo w sposób znaczący nie zwiększało niebezpieczeństwa dla dobra chronionego prawem"; zob. wyrok Sądu Najwyższego z dnia 1 grudnia 2000 roku, IV KKN 509/98, OSNKW 2001, nr 5-6, poz. 45.

18 Tak też S. Kowalski, op. cit. 
opłat egzekucyjnych podlegających przekazaniu oraz ,przekazuje w niewłaściwej wysokości" wiąże się z wywołaniem ustawowo stypizowanego stanu rzeczy (skutku). Znamiona „nie przekazuje” i „przekazuje w niewłaściwej wysokości” zawierają w sobie element uszczerbku po stronie budżetu państwa. Zależnie od jego wysokości możliwa jest różna kwalifikacja prawna zachowania sprawczego. I tak przepis art. 57a k.k.s. przewiduje dwa typy przestępstw skarbowych — podstawowy $(\S 1)$ i uprzywilejowany (wypadek małej wartości) $(\S 2)$ - oraz jeden typ wykroczenia skarbowego $(\S 3)$. Zarysowane w tych przepisach różnice dotyczą dwóch elementów: na płaszczyźnie strony przedmiotowej wysokości kwoty opłaty egzekucyjnej oraz na płaszczyźnie ustawowego zagrożenia (wynikającego ze wskazanej wyżej różnicy) odmiennym określeniem ustawowego zagrożenia. Jeżeli jest ona małej wartości (nie przekracza dwustukrotności minimalnego wynagrodzenia w czasie czynu - art. $53 \S 14$ k.k.s.), to właściwy jest typ uprzywilejowany z $\S 2$. Jeżeli kwota niewpłaconej opłaty przekroczy tę kwotę, to przyjąć należy kwalifikację na podstawie art. 57a § 1 k.k.s. Wreszcie w sytuacji, gdy kwota niewpłaconej opłaty egzekucyjnej nie przekroczy ustawowego progu (pięciokrotności minimalnego wynagrodzenia w czasie czynu — art. $53 \S 6$ k.k.s.), to zachowanie osoby należy ocenić przez pryzmat art. $57 \mathrm{a} \S 3$ k.k.s.

Określone w art. 57a $\S 1-3$ k.k.s. typy czynów zabronionych mają charakter umyślny. Mogą one wystąpić zarówno w formie zamiaru bezpośredniego, jak i wynikowego. Nie jest przy tym konieczna żadna szczególna motywacja sprawcy nieprzekazującego opłaty egzekucyjnej bądź przekazującego ją w nienależnej (zaniżonej) wysokości. Dla przypisania strony podmiotowej przestępstwa stypizowanego w art. 57a k.k.s. konieczne jest stwierdzenie, że sprawca obejmował świadomością i wolą (w postaci chęci lub co najmniej godzenia się) wszystkie elementy strony przedmiotowej tego typu czynu zabronionego. Sprawca musi być zatem świadomy, że swoim zachowaniem - nie przekazując na rachunek właściwego urzędu skarbowego opłat podlegających przekazaniu we właściwym terminie bądź przekazując ją w niewłaściwej wysokości — pomniejsza należności budżetu państwa $\mathrm{z}$ tytułu opłaty egzekucyjnej ${ }^{19}$.

Czyniąc uwagi w zakresie typów czynów zabronionych w art. 57a § 1-3 k.k.s., nie sposób pominąć ustawowego zagrożenia. Każdy z trzech typów powiązany jest z inną sankcją: typ podstawowy przestępstwa skarbowego z $§ 1$ zagrożony jest karą grzywny do 720 stawek dziennych albo karą pozbawienia wolności do lat pięciu, albo obiema tymi karami łącznie (sankcja alternatywno-kumulatywna); typ uprzywilejowany przestępstwa skarbowego z $\S 2$ zagrożony jest karą grzywny do 720 stawek dziennych, zaś w przypadku wykroczenia skarbowego ustawodawca przewidział grzywnę do dwudziestokrotności minimalnego wynagrodzenia. Wysokość zagrożenia przewidzianego za typ podstawowy zatrzymania opłaty egzekucyjnej odpowiada sankcjom najpoważniejszych przestępstw skarbowych,

19 Ibidem, s. 26. 
na przykład oszustwa podatkowego (art. 56 k.k.s) czy bezpodstawnego zwrotu podatku (art. 76 k.k.s.). Eliminuje tym samym możliwość skorzystania z instytucji zaniechania sprawy w postaci dobrowolnego poddania się odpowiedzialności oraz odstąpienia od wymierzenia kary ${ }^{20}$. Rodzi się jednak pytanie, czy wartość dobra chronionego prawnie w art. 57a k.k.s. i abstrakcyjny stopień karygodności tego czynu faktycznie przemawiają za wprowadzeniem takiej sankcji?

Porównując analizowany typ czynu zabronionego ze stopniem ochrony innych należności publicznych w k.k.s, można wyrazić pogląd, że wymiar ustawowego zagrożenia typu czynu zabronionego z art. 57a $\S 1$ k.k.s. jest przejawem pozbawionej racjonalności polityki karnej. W jego przypadku ustawowe zagrożenie karą powinno zostać określone na poziomie sankcji grożącej sprawcy przestępstwa $\mathrm{z}$ art. $77 \S 1$ k.k.s., to jest czynu polegającego na niewpłaceniu w terminie podatku pobranego przez płatnika lub inkasenta. Jest on penalizowany sankcją alternatywno-kumulatywną kary grzywny do 720 stawek dziennych i kary pozbawienia wolności do lat trzech. Co więcej, ustawodawca - w przeciwieństwie do art. 77 § 4 i 5 k.k.s. - nie przewidział możliwości nadzwyczajnego złagodzenia kary, a nawet odstąpienia od wymierzenia jej lub środka karnego, jeżeli przed wszczęciem postępowania $\mathrm{w}$ sprawie o przestępstwo skarbowe określone $\mathrm{w} \S 1$ lub 2 wpłacono w całości pobraną opłatę egzekucyjną na rzecz właściwego urzędu skarbowego. Przedstawia to przykład naruszenia spójności wewnętrznej k.k.s., gdyż w przypadku zbieżnego typu czynu zabronionego normującego ochronę należności podatkowej występuje możliwość redukcji odpowiedzialności karnoskarbowej, tymczasem w przypadku typu czynu zabronionego $\mathrm{z}$ art. 57a k.k.s. takiej możliwości nie przewidziano.

\section{PRZESTĘPSTWO NIEDOPEŁNIENIA LUB NIEPRAWIDŁOWEGO WYPEŁNIENIA OBOWIĄZKÓW INFORMACYJNYCH O UZYSKANYCH OPŁATACH EGZEKUCYJNYCH}

Drugie przestępstwo, które ściśle łączy się z odpowiedzialnością komornika sądowego, zostało określone $\mathrm{w}$ art. 57b k.k.s. Jego istota polega na niedopełnieniu lub nieprawidłowym wypełnieniu obowiązków informacyjnych o uzyskanych opłatach egzekucyjnych. Przepis art. 57b k.k.s. przewiduje dwa typy czynu zabronionego: typ podstawowy przewidziany $\mathrm{w}$ art. $57 \mathrm{~b} \S 1$ k.k.s. oraz wykroczenie niedopełnienia lub nieprawidłowego wypełnienia obowiązków informacyjnych o uzyskanych opłatach egzekucyjnych jako wypadek mniejszej wagi opisane $\mathrm{w}$ art. $57 \mathrm{~b} \S 3$ k.k.s. Mają one charakter bezskutkowy.

${ }^{20}$ Krytycznie w stosunku do ujęcia sankcji w przypadku art. 57a i 57b k.k.s. zob. ibidem, s. 30. 
Przedmiotem ochrony typów czynów zabronionych z art. 56b k.k.s. jest mienie Skarbu Państwa, zaś indywidualnym przedmiotem ochrony — prawidłowość realizacji obowiązków instrumentalnych w postaci przekazywania informacji nakierowanych na monitorowanie naliczanych opłat egzekucyjnych oraz rzeczywiste ich odprowadzenie na rzecz Skarbu Państwa. Należy dodać, że oba typy czynów zabronionych mają charakter deliktu indywidualnego, którego sprawcą może być podmiot posiadający status komornika sądowego lub osoba zajmująca się jego sprawami gospodarczymi, w szczególności finansowymi na podstawie art. 9 $\S 3$ k.k.s. Jeśli zaś chodzi o znamiona określające czynność wykonawczą, trzeba podnieść, że przepis art. 57b k.k.s. ma charakter blankietowy, jego treść zawiera bowiem odesłanie do regulacji art. 149 ust 5 ustawy o KS, która konkretyzuje treść znamion typu czynu zabronionego. Ten ostatni przepis stanowi, że komornik jest obowiązany złożyć do urzędu skarbowego właściwego ze względu na siedzibę kancelarii miesięczną informację o uzyskanych opłatach egzekucyjnych oraz opłatach egzekucyjnych podlegających przekazaniu zgodnie z art. 149 ust. 2 ustawy o KS w terminie do dziesiątego dnia miesiąca kalendarzowego następującego po miesiącu, w którym zostały uzyskane. Informacja ta stanowi dowód księgowy.

Przestępstwo niedopełnienia lub nieprawidłowego wypełnienia obowiązków informacyjnych o uzyskanych opłatach egzekucyjnych operuje trzema znamionami opisującymi czynności sprawcze: „nie składa”, „,składa po terminie” oraz „,podaje dane niezgodne ze stanem rzeczywistym”. Znamiona „nie składa” oraz „składa po terminie" tylko pozornie opisują dwie różne czynności sprawcze ${ }^{21}$. W rzeczywistości sprawca przekracza zakreślony art. 149 ust. 2 ustawy o KS termin do złożenia miesięcznej informacji o uzyskanych opłatach egzekucyjnych oraz opłatach egzekucyjnych po potrąceniu wynagrodzenia prowizyjnego komornika, które podlegają przekazaniu na rachunek urzędu skarbowego właściwego ze względu na siedzibę kancelarii. W przypadku obu czynności sprawczych mamy do czynienia z zaniechaniem terminowego wykonania wskazanego powyżej obowiązku. Warto jednak zauważyć, że w wypadku znamienia złożenia po terminie sprawca, po zaniechaniu prawem nakazanego mu działania, podejmuje się wykonania ciążącego na nim obowiązku, tyle tylko, że po terminie. Grzegorz Łabuda słusznie twierdzi, że rozróżnienie obu czynności sprawczych opiera się na spóźnionym wykonaniu obowiązku, wcześniejsze zaniechanie zaś jest ich mianownikiem wspólnym ${ }^{22}$. Trzecie znamię czynnościowe polega na podaniu w przekazywanej informacji danych niezgodnych ze stanem rzeczywistym. Jest ono związane z zawartymi w art. 149 ust 5 ustawy o KS elementami, jakie ujawnia się w tej informacji. Są to miesięczne dane o uzyskanych opłatach egzekucyjnych oraz o opłatach egzekucyjnych po potrąceniu wynagrodzenia prowizyjnego komornika, które podlegają przekazaniu na rachunek urzędu skarbowego właściwego ze względu na siedzibę

21 Zob. G. Łabuda, op. cit., komentarz do art. 56a k.k.s, pkt 6.

22 Szerzej zob. ibidem. 
kancelarii. Pominięcie $\mathrm{w}$ takim zestawieniu określonej opłaty będzie realizacją znamienia podania danych niezgodnych ze stanem rzeczywistym. W każdym $\mathrm{z}$ trzech przypadków karalne będą zachowania sprawcze $\mathrm{w}$ razie ich umyślnego popełnienia. W grę zatem wchodzi zamiar bezpośredni i ewentualny.

Wszystkie typy czynów zabronionych z art. 57b k.k.s. mają charakter bezskutkowy. Jakkolwiek czyn zabroniony podania nierzetelnych danych jest związany $\mathrm{z}$ dodatkową czynnością polegającą na niewłaściwym zestawieniu opłat, to dla jego popełnienia nie jest konieczne spowodowanie uszczerbku po stronie budżetu państwa. Szczególnego znaczenia nabiera kwalifikacja czynu z art. 57b $\S 2$ k.k.s. w kategoriach wypadku mniejszej wagi ${ }^{23}$. Wypadek taki posiada swoją definicję legalną $\mathrm{w}$ art. $53 \S 8$ k.k.s., zgodnie z którą jest to czyn zabroniony jako wykroczenie skarbowe, które w konkretnej sprawie, ze względu na jej szczególne okoliczności - zarówno przedmiotowe, jak i podmiotowe - zawiera niski stopień społecznej szkodliwości czynu, zwłaszcza gdy uszczuplona lub narażona na uszczuplenie należność publicznoprawna nie przekracza ustawowego progu z art. $53 \S 6$ k.k.s,, a sposób i okoliczności popełnienia czynu zabronionego nie wskazują na rażące lekceważenie przez sprawcę porządku finansowoprawnego lub reguł ostrożności wymaganych $\mathrm{w}$ danej sytuacji, albo sprawca dopuszczający się czynu zabronionego, którego przedmiot nie przekracza kwoty małej wartości, czyni to z pobudek zasługujących na uwzględnienie (na przykład długość nieprzekazywanych informacji czy charakter informacji niezgodnych ze stanem rzeczywistym). Twierdzi się także, że w odniesieniu do czynu zabronionego z art. 57b $\S 2$ k.k.s. za wypadek mniejszej wagi może zostać uznane „zachowanie sprawcy, który rzetelnie rozliczył opłaty egzekucyjnie, ale z uwagi na realizowanie innych jeszcze, pilnych, ciążących na nim obowiązków, nie wykonał w terminie obowiązku dotyczącego złożenia informacji, które ostatecznie złożył niedługo po ustawowo określonym terminie"24. Nawet podzielając powyższy przykład, należy szukać rozwiązania bardziej uniwersalnego. W tym zakresie można odwołać się do stanowiska Sądu Najwyższego wyrażonego w postanowieniu z dnia 13 czerwca 2002 roku, w którym stwierdzono, że o uznaniu konkretnego czynu zabronionego za wypadek mniejszej wagi decyduje ocena jego społecznej szkodliwości jako zmniejszonej do stopnia uzasadniającego wymierzenie kary według skali zagrożenia ustawowego przewidzianego w przepisie wyodrębniającym wypadek

${ }^{23} \mathrm{Na}$ temat wypadku mniejszej wagi zob. P. Lewczyk, Wypadek mniejszej wagi $w$ polskim kodeksie karnym (uwagi de lege lata $i$ postulaty de lege ferenda), „Prokuratura i Prawo” 2008, nr 7-8, s. 28-38; K. Frąckowiak, Wypadek mniejszej wagi w prawie karnym skarbowym, „Studia Prawnoustrojowe” 2019, nr 44, s. 75-87; J. Brzezińska, Kilka uwag o „wypadku mniejszej wagi”, „Nowa Kodyfikacja Prawa Karnego" 31, 2014, s. 37-50; E. Plebanek, Wypadek mniejszej wagi kilka uwag w sporze o charakter instytucji i jego praktyczne konsekwencje, „Czasopismo Prawa Karnego i Nauk Penalnych” 2011, s. 1-14; B. Stefańska, Wypadek mniejszej wagi w polskim prawie karnym, „Ius Novum” 2017, nr 1, s. 48-63.

24 S. Kowalski, op. cit., s. 39. 
mniejszej wagi z kategorii przestępstw określonego typu ${ }^{25}$. Określenie stopnia społecznej szkodliwości czynu należy do sfery ustaleń faktycznych w sprawie. Dlatego też sąd prowadzący ustalenia w tym zakresie zobowiązany jest każdorazowo zbadać

wszystkie okoliczności istotne z punktu widzenia znamion strony przedmiotowej i podmiotowej czynu zabronionego i nadać im właściwe znaczenie w celu uściślenia ich wpływu na stopień społecznej szkodliwości. W ten tylko sposób sąd orzekający prawidłowo oznaczy wagę czynu zabronionego, wyrażającą się stopniem społecznej szkodliwości, co z kolei umożliwi mu rozstrzygnięcie, czy stanowi on wypadek mniejszej wagi, jeśli ta postać typu przestępstwa jest przewidziana w ustawie. Wynika $\mathrm{z}$ tego, że do naruszenia przepisu ustanawiającego wypadek mniejszej wagi w ramach typu danego przestępstwa dojdzie wtedy, gdy sąd pominie ocenę okoliczności, które powinny mieć wpływ na ustalenie natężenia społecznej szkodliwości czynu bądź nada znaczenie okolicznościom nieistotnym w tym względzie ${ }^{26}$.

Kończąc uwagi na tle art. 57b k.k.s., nie sposób pominąć ustawowego zagrożenia. Stypizowane w $\S 1$ przestępstwo skarbowe jest opatrzone sankcją kary grzywny do 720 stawek dziennych. Sprawca ma zatem zawsze możliwość skorzystania $\mathrm{z}$ dobrodziejstwa dobrowolnego poddania się odpowiedzialności z art. 17 k.k.s. oraz — po spełnieniu warunków ustawowych — skorzystać z odstąpienia od wymierzania kary (art 19 k.k.s). Wykroczenie skarbowe z $\S 2$ jest zagrożone grzywną kwotową od jednej dziesiątej minimalnego wynagrodzenia do dwudziestokrotności minimalnego wynagrodzenia.

\section{PODSUMOWANIE}

Przedstawione uwagi na temat odpowiedzialności komornika sądowego za nieprawidłowe rozliczenie opłaty egzekucyjnej na podstawie przepisów Kodeksu karnego skarbowego pozwalają wyrazić pogląd, że nowe typy czynów zabronionych z art. 57a i 57b k.k.s. naruszają zasadę, zgodnie z którą ustawodawca, tworząc nową regulację prawną, bezwzględnie powinien przestrzegać reguły stanowienia jasnego, racjonalnego i spójnego systemowo prawa wyznaczonego standardami przyzwoitej legislacji. Tymczasem w przypadku wprowadzenia przestępstwa zatrzymania opłaty egzekucyjnej i przestępstwa niedopełnienia lub

25 Postanowienie Sądu Najwyższego z dnia 13 czerwca 2002 roku, V KKN 544/00, ONSWK 2002, nr 9-10, poz. 73.

26 Por. wyrok Sądu Najwyższego z dnia 14 listopada 1997 roku, V KKN 4/97, OSNKW 1998, z. 3-4, poz. 17. Przywołana wypowiedź Sądu Najwyższego bazuje na koncepcji przedmiotowopodmiotowej „wypadek mniejszej wagi”, wedle której uznawany jest on w doktrynie za postać przestępstwa uprzywilejowaną ze względu na dominowanie okoliczności zmniejszających zawartość bezprawia, a w konsekwencji także stopnia karygodności czynu (por. K. Buchała, Glosa do wyroku Sądu Najwyższego z dnia 9 października 1996 r., V KKN 79/96, „Państwo i Prawo” 1997, z. 9, s. 111 n.; T. Hajduk, Wypadki przestępstw mniejszej wagi, „Prokuratura i Prawo” 2002, z. 5, s. 57 n. 
nieprawidłowego wypełnienia obowiązków informacyjnych o uzyskanych opłatach egzekucyjnych brakuje racjonalnego uzasadnienia przyjęcia nowych typów czynów zabronionych z art. 57a i 57b k.k.s. Ustawodawca nie wskazał także, dlaczego odpowiedzialność komornika sądowego jako funkcjonariusza publicznego powinna znaleźć się w k.k.s. oraz $\mathrm{w}$ jakim zakresie łączy się $\mathrm{z}$ pozostałymi przestępstwami i wykroczeniami skarbowymi stypizowanymi w k.k.s. Pojawienie się takiego rozwiązania może prowadzić do uznania go za niekonstytucyjne z uwagi na naruszenie zasady proporcjonalności poprzez stworzenie nadmiernej ingerencji w sferę wolności osobistej jednostki. Zdaniem Trybunału Konstytucyjnego z zasady tej wypływa wniosek o - po pierwsze - przyjmowaniu danej regulacji tylko wówczas, gdy jest niezbędna dla ochrony interesu publicznego, z którym jest powiązana; po drugie - o nakazie kształtowania danej regulacji w sposób zapewniający osiągnięcie zamierzonych skutków; i wreszcie po trzecie - o wymogu zachowania proporcji między efektami wprowadzonej regulacji a ciężarami (względnie niedogodnościami) wynikającymi z niej dla obywateli27. Odwołanie się do zasady proporcjonalności z art. 31 ust. 3 Konstytucji RP powinno pozwolić na weryfikację motywów ustawodawcy w perspektywie konieczności posługiwania się sankcją karną dla ochrony określonego dobra prawnego oraz określenia dopuszczalnego stopnia intensywności tej sankcji ${ }^{28}$. Z uwagi na to, że uzasadnienie projektu ustawy o komornikach sądowych przemilcza ratio legis typów czynów zabronionych $\mathrm{z}$ art. 57a i 57b k.k.s. wskazana weryfikacja nie jest możliwa.

Dodać należy, że przy ocenie tego, czy zakaz nadmiernej ingerencji w sferę wolności jednostki został zrealizowany, to znaczy przy ocenie tego, czy ingerencja była wyrazem konieczności i została przeprowadzona tylko w koniecznym wymiarze, uwzględnia się specyfikę poszczególnych praw i wolności; surowsze standardy dotyczą tu praw osobistych i politycznych niż ekonomicznych i socjalnych ${ }^{29}$. Istotą tak rozumianego zakazu nadmiernej ingerencji jest uznanie, że ustawodawca nie może ustanawiać ograniczeń przekraczających pewien stopień uciążliwości, a zwłaszcza zapoznających proporcję pomiędzy stopniem naruszenia uprawnień jednostki a rangą interesu publicznego, który ma w ten sposób podlegać ochronie. W tym ogólnym ujęciu zakaz nadmiernej ingerencji pełni funkcję ochronną w stosunku do wszystkich praw i wolności jednostki. Jego adresatem jest państwo, które winno działać wobec jednostki w sposób wyznaczony rzeczywistą potrzebą. Nie można zapominać również o tym, że zasada proporcjonalności sensu stric-

27 Orzeczenie Trybunału Konstytucyjnego z dnia 26 kwietnia 1995 roku, sygn. K. 11/94, OTK w 1995 roku, cz. 1, poz. 12.

28 W. Wróbel, Spór o ,dostateczny poziom represyjności” prawa karnego w płaszczyźnie legislacyjnej, [w:] Represyjność polskiego prawa karnego, red. A.J. Szwarc, Poznań 2008, s. 18.

29 Por. wyrok Trybunału Konstytucyjnego z dnia 20 czerwca 2005 roku, sygn. K 4/04, OTK-A 2005, Nr 6, poz. 64; orzeczenie Trybunału Konstytucyjnego z dnia 26 kwietnia 1995 roku, sygn. K.11/94, OTK w 1995 roku, cz. 1, poz. 12; orzeczenie Trybunału Konstytucyjnego z dnia 31 stycznia 1996 roku, sygn. K. 9/95, OTK ZU 1996, nr 1, poz. 2. 
to nakazuje tylko zachowanie odpowiedniej proporcji między efektem regulacji a ciężarem nakładanym na jednostkę. Wyznacza ona maksymalną dopuszczalną granicę intensywności ingerencji prawnokarnej. $Z$ kolei zasada konieczności nakazuje ustalenie wysokości kary na minimalnym poziomie, który pozwala zapewnić skuteczną ochronę danego dobra.

Tworząc nowe typy czynów zabronionych z art. 57a i 57b k.k.s. i wprowadzając surowe zagrożenie karą, porównywalne do najcięższych przestępstw skarbowych, ustawodawca w sposób jednoznaczny naruszył nakaz zachowania spójności wewnętrznej. W omówieniu przestępstwa zatrzymania opłaty egzekucyjnej pominięto instrumenty zmniejszające stopień penalizacji, takie jak na przykład nadzwyczajne złagodzenie kary czy odstąpienie od jej wymierzenia, które funkcjonują w przypadku sprawcy przestępstwa niewpłacenie pobranego podatku $\mathrm{z}$ art. 77 § 4 i 5 k.k.s. Może to sugerować, że przyjęte sankcje karne hołdują idei odhumanizowanej prewencji generalnej negatywnej, prewencji, która pozostaje w sprzeczności nie tylko z godnością jednostki, ale i zasadą odpowiedzialności karnej w demokratycznym państwie prawa.

\section{THE RESPONSIBILITY OF A JUDICIAL ENFORCEMENT OFFICER FOR IMPROPER SETTLEMENT OF THE ENFORCEMENT FEE UNDER THE PROVISIONS OF THE FISCAL PENAL CODE}

\section{Summary}

The article presents new types of criminal acts concerning the responsibility of a judicial enforcement officer for improper settlement of the enforcement fee under the provisions of the Fiscal Penal Code. The author analyses an element of new offences (Articles 57a and 57b of the Fiscal Penal Code) and makes a critical assessment of them in the context of the proportionality principle and the internal consistency of the provisions of the Fiscal Penal Code. In the final analysis the author comes to a conclusion that there is no rational justification for adopting new criminal liability offenses for judicial enforcement officer.

Keywords: a judicial enforcement officer, Fiscal Penal Code, the financial criminal liability, rational legislator

\section{BIBLIOGRAFIA}

Bartosiewicz A., Kubacki R., VAT. Komentarz, Warszawa 2007.

Brzezińska J., Kilka uwag o „wypadku mniejszej wagi”, „Nowa Kodyfikacja Prawa Karnego” 31, 2014.

Buchała K., Glosa do wyroku SN z dnia 9 października 1996 r., V KKN 79/96, „Państwo i Prawo” 1997, z. 9.

Frąckowiak K., Wypadek mniejszej wagi w prawie karnym skarbowym, „Studia Prawnoustrojowe” 2019, nr 44.

Hajduk T., Wypadki przestępstw mniejszej wagi, „Prokuratura i Prawo” 2002, z. 5. 
Kalinowski M., Komornik jako płatnik podatku od towarów i usług. Uwagi na marginesie uchwały Sądu Najwyższego z dnia 15 grudnia 2006 r., III CZP 115/06, „Przegląd Prawa Egzekucyjnego" 2008, nr 6-9.

Kardas P., G Łabuda., Razowski T., Kodeks karny skarbowy. Komentarz, Warszawa 2017.

Kowalski S., Czyny zabronione dotyczace optat egzekucyjnych w Kodeksie karnym skarbowym, „Przeglad Prawa Egzekucyjnego” 2020, nr 1.

Lewczyk P., Wypadek mniejszej wagi w polskim kodeksie karnym (uwagi de lege lata i postulaty de lege ferenda), „Prokuratura i Prawo” 2008, nr 7-8.

Nalikowski F., Odpowiedzialność karna skarbowa komornika sadowego jako płatnika podatku od towarów i ustug, „Prawo Budżetowe Państwa i Samorządu” 2016, nr 1.

Plebanek E., Wypadek mniejszej wagi — kilka uwag w sporze o charakter instytucji i jego praktyczne konsekwencje, „Czasopismo Prawa Karnego i Nauk Penalnych” 2011, nr 1.

Stefańska B., Wypadek mniejszej wagi w polskim prawie karnym, „Ius Novum” 2017, nr 1.

Wojnicz P., Status komornika jako płatnika podatku VAT w egzekucji sądowej, „Przegląd Prawa Egzekucyjnego" 2007, nr 1-2.

Wróbel W., Spór o „dostateczny poziom represyjności” prawa karnego w płaszczyźnie legislacyjnej, [w:] Represyjność polskiego prawa karnego, red. A.J. Szwarc, Poznań 2008. 